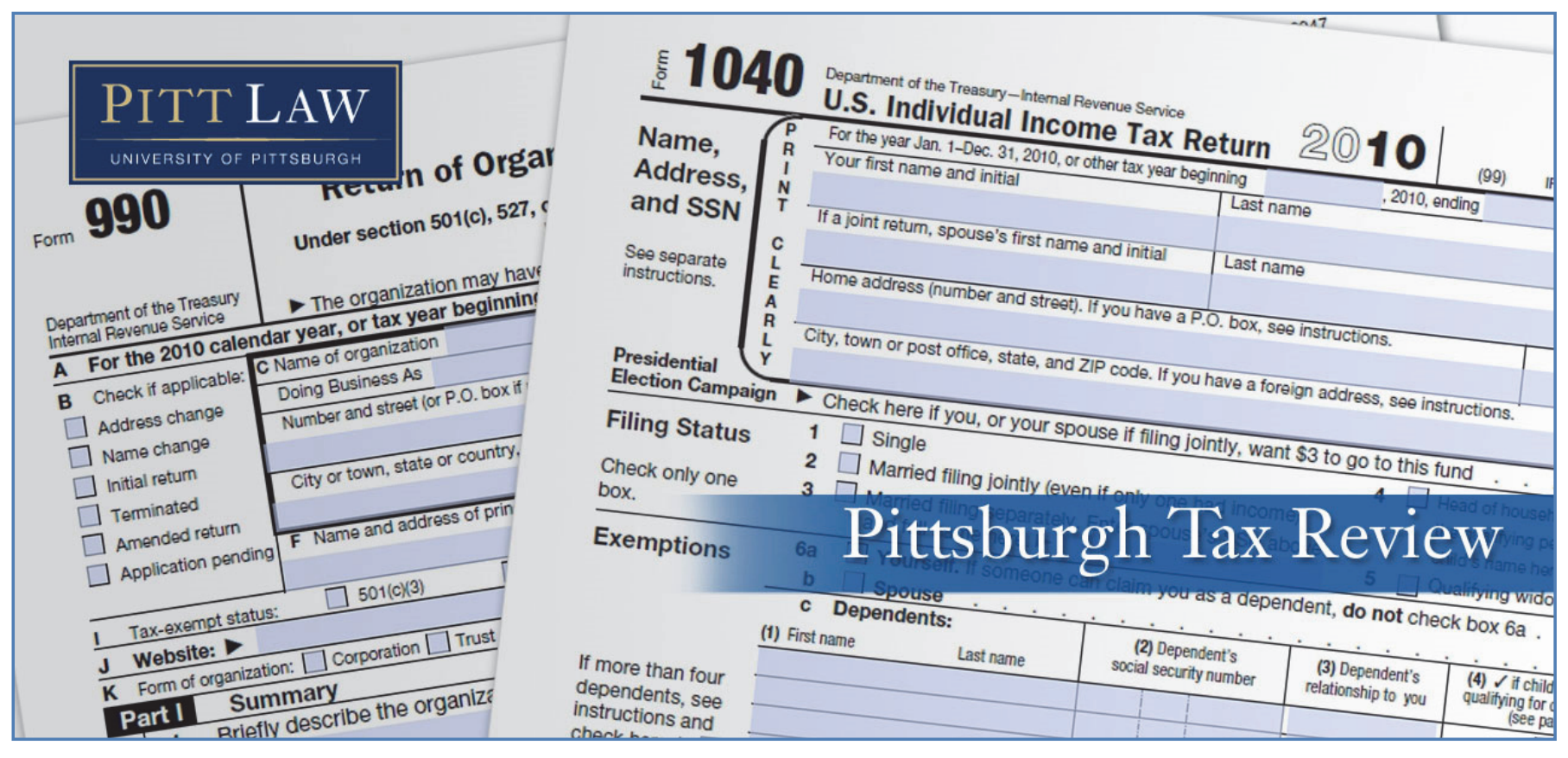

Volume 18 (2021) | ISSN 1932-1821 (print) 1932-1996 (online)

DOI 10.5195/taxreview.2021.132 | http://taxreview.law.pitt.edu

\author{
BEYOND THE "MADE IN AMERICA TAX PLAN": GILTI AND \\ INTERNATIONAL TAX COOPERATION'S NEXT GOLDEN AGE
}

Steven A. Dean

\title{
(cc) EY-NO-ND
}

This work is licensed under a Creative Commons Attribution-Noncommercial-No Derivative Works 3.0 United States License.

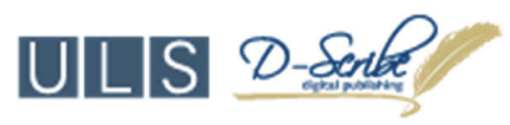

This journal is published by the University Library System of the University of Pittsburgh as part of its D-Scribe Digital Publishing Program, and is cosponsored by the University of Pittsburgh Press. 


\title{
BEYOND THE "MADE IN AMERICA TAX PLAN": GILTI AND INTERNATIONAL TAX COOPERATION'S NEXT GOLDEN AGE
}

\author{
Steven A. Dean ${ }^{*}$
}

Tumultuous times can be particularly difficult for the vulnerable. That may be no less true in the international tax context than it is elsewhere, but disruptive change can also open the door to greater participation by, and rewards for, those long treated as outsiders. With international tax cooperation's first golden age receding into history, new priorities have begun to take root. Unprecedented challenges buffet the international tax regime, suggesting that its future may depend less on its capacity to shield businesses from taxation than on its ability to find common ground among very different states.

International tax cooperation has long held a potent appeal even for states with outsized influence and power. ${ }^{1}$ Resting on a patchwork quilt of mismatched national tax systems, international tax rules have drawn strength from states' willingness to make generous concessions to one another. When an investment or a business spans a border, two sovereigns could assert competing tax claims on the resulting profits. ${ }^{2}$ Surprisingly often, they have

\footnotetext{
${ }^{*}$ Professor of Law, Brooklyn Law School.
}

(C) 2021 Steven A. Dean. All rights reserved. This Article benefited from helpful comments from Kim Brooks, Kim Clausing and Susie Morse and from excellent research assistance from Kalina Hannsz and Annemarie Mierzejewski.

${ }^{1}$ See Michael J. Graetz, Taxing International Income: Inadequate Principles, Outdated Concepts and Unsatisfactory Policies, 26 BROOK. J. INT'L L. 1357, 1390 (2001) (“At least since the 1920s, the international tax policy of the United States has been premised on the idea that we can improve our lot through multilateral cooperation and agreement.").

${ }^{2}$ See Tsilly Dagan, The Tax Treaties Myth, 32 N.Y.U. J. INT’L L. \& PoL. 939, 942 (2000) (“The classic case of double taxation arises when a resident of one country produces income in another country and is subject to tax on that income by both her country of residence as well as the country in which her income is earned (the host country). Double taxation is often cited as a major obstacle to unfettered economic progress."); Eric M. Zolt, Tax Treaties and Developing Countries, 72 TAX L. REV. 111, 115 (2018) ("For countries to realize the benefits from cross-border activity, they need to ensure that the total taxes imposed (by them and other countries) are not so high as to make engaging in these activities economically unattractive. If two countries have the right to tax an activity or investment, and each

Pitt Tax Review | ISSN 1932-1821 (print) 1932-1996 (online)

DOI 10.5195/taxreview.2021.132 | http://taxreview.law.pitt.edu 
not. ${ }^{3}$ Precisely the reverse can be true, with states treating the right to tax like a hot potato. ${ }^{4}$

In the wake of the Great Recession that followed the 2008 financial crisis, the once-robust neoliberal consensus that sustained that cooperative approach began to fray. ${ }^{5}$ The reciprocal deference to the claims of other states that once delighted scholars and served as a boon to international commerce has come to seem anachronistic. ${ }^{6}$ As the enormous subsidies it delivers to multinationals have come into focus, the call for shared sacrifice to produce collective benefits through economic growth ring increasingly hollow.

imposes tax at a significant tax rate (say 35\%), then the very high pretax rate of return required for an investment to be economically viable will result in relatively little cross-border activity.").

${ }^{3}$ See Allison Christians, Sovereignty, Taxation and Social Contract, 18 MinN. J. InT'L L. 99, 110 n.31 (2009) (describing "double non-taxation" or "the simultaneous non-taxation by multiple jurisdictions" as when "each country . . refrain[s] from exercising an otherwise appropriate jurisdiction to tax, either out of deference to the other (arguably respecting the other's sovereign entitlement) or to attract foreign investment (arguably respecting its own sovereign entitlement not to tax")); Graetz, supra note 1 , at 1364 .

${ }^{4}$ In the E.U. state aid cases against Apple and others, the United States and Ireland fought for the right not to tax. See Ruth Mason, Identifying Illegal Subsidies, 69 AM. U. L. REV. 479, 516-22 (2019) (explaining why, even as a theoretical matter, neither Ireland nor the United States could be compelled to tax Apple's profits); Daniel Shaviro, Friends Without Benefits? Treasury and EU State Aid, 83 TAX NOTES INT'L 1067, 1079 (2016) (suggesting that U.S. resistance to Apple paying tax reflects the reality that "U.S. multinationals' influence" is "more likely to be too strong than too weak").

${ }^{5}$ See Jeremy Leaman \& Attiya Waris, Introduction: Why Tax Justice Matters in Global Economic Development, in TaX Justice and the Political EConomy of Global CAPITAlism, 1945 TO THE PRESENT 1, 1 (Jeremy Leaman \& Attiya Waris eds., 2013) (noting that in the wake of the 2008 financial crisis - long tolerated in the name of neoliberalism - the problems posed by corporate tax avoidance and by tax competition with low-tax jurisdictions "have now only been deemed worrying because their contribution to the global crises and their associated destruction of wealth and social equilibrium has become palpable").

${ }^{6}$ Rebecca M. Kysar, Unraveling the Tax Treaty, 104 MinN. L. REV. 1755, 1756 (2020) (“Although tax treaties may have, at one time, served salutary purposes, modern circumstances call into question their necessity. ... Instead of alleviating double taxation ... treaties are the means to achieve double nontaxation."). Underlying the skepticism of that deference is the threat of too little tax, which would violate what Professor Reuven Avi-Yonah calls the "single tax principle." See Reuven S. Avi-Yonah, Who Invented the Single Tax Principle: An Essay on the History of U.S. Treaty Policy, 59 N.Y. L. SCH. L. ReV. 305, 306 (2014).

${ }^{7}$ See Graetz, supra note 1, at 1363 ("Frequently, the normative and policy discussions of international income taxation in the literature, including not only the academic publications of both economists and lawyers, but also - and perhaps most importantly — most of the key serious government analyses containing any normative discussion, begin and end with an assumption — not an argument - that the proper goal for U.S. international tax policy is advancing worldwide economic efficiency.”).

Pitt Tax Review | ISSN 1932-1821 (print) 1932-1996 (online)

DOI 10.5195/taxreview.2021.132 | http://taxreview.law.pitt.edu 
International tax cooperation's longstanding success came because ofnot despite-its lofty aspirations. The question of why states obey international law can be a puzzle. Legitimacy - and the compliance pull it exerts over states - offers one answer that explains the perseverance of the international tax regime. ${ }^{8}$ Simply put, influential states harnessed legal instruments with sterling pedigrees to contain a compelling threat to the world's collective welfare. ${ }^{9}$ Fueled by the legitimacy generated by states' formal embrace of its pursuit of collective benefits, international tax cooperation grew strong.

Over the last two decades, shared sacrifice has yielded to centralized authority. ${ }^{10}$ The dawn of a new golden age of international tax cooperation will require more, a higher purpose worthy of the vast shared undertaking it represents. One path forward would be to shape international tax rules to deliver benefits principally to the least well-off states. ${ }^{11}$ Such an approachTax Sparing 2.0-would revive a proud history of mission-driven international tax cooperation, helping to restore its lost legitimacy. ${ }^{12}$

\footnotetext{
${ }^{8}$ See Steven A. Dean, Neither Rules nor Standards, 87 Notre DAME L. REv. 537, 561-62 (2011) (discussing the role and sources of legitimacy and compliance pull in the international tax regime).

${ }^{9}$ The League of Nations developed the bilateral treaties that would ultimately be replicated thousands of times to form the core of today's international tax regime. See SUNITA JOGARAJAN, DOUBLE TAXATION AND THE LEAGUE OF NATIONS 3-4 (2018).

${ }^{10}$ The OECD Secretariat, for example, has begun to play an increasingly central role. Allison Christians, A Unified Approach to International Tax Consensus, 96 TAX NOTES INT'L 497, 497 (2019) (noting that "it is unlike the vast majority of tax work undertaken by the OECD in that it expressly declines to represent the views of the 36 member states, let alone the 134 inclusive framework members").

${ }^{11}$ See TSilly Dagan, InTERnational Tax Policy: Between Competition and CoOPERATION 189 (2018) (concluding that for "a multilateral regime established through cooperation to be justified it must improve (or at least not worsen) the welfare of the least well-off citizens in all the cooperating states"); Press Release, Economic and Social Council, Corporate Tax Reform Must Focus on Developing Countries' Needs, Combating Inequality, Speakers Tell Special Meeting of Economic and Social Council, U.N. Press Release ECOSOC/6978 (Apr. 19, 2019) ("However, any reform of tax rules must pay special attention to the needs of developing countries .... [A]ny new measures must work towards a fair system that reduces inequalities.").

${ }^{12}$ See Arthur Cockfield, The Limits of the International Tax Regime as a Commitment Projector, 33 VA. TAX REV. 59, 70 (2013) (concluding that the international tax regime's "initial purpose" was "to promote peace and prosperity").
}

Pitt Tax Review | ISSN 1932-1821 (print) 1932-1996 (online) DOI 10.5195/taxreview.2021.132 | http://taxreview.law.pitt.edu 


\section{INTERNATIONAL TAX COOPERATION}

When a business extends its reach beyond its home state, it does so to seize a profit opportunity. Absent some form of accommodation, the additional earnings resulting from that expansion might be subject to the income tax of both the venture's home jurisdiction and its new host jurisdiction. International tax rules provide a series of imperfect-and generous - responses to that potential burden.

Simply by virtue of its default rules, the U.S. income tax allows a venture to deduct taxes paid to a host state just like other business expenses, such as electricity or rent. ${ }^{13}$ The U.S. income tax goes further, affording foreign income taxes a special status that most business costs do not enjoy. Our hypothetical cross-border business could, within limits, credit each dollar of foreign taxes against a dollar of its U.S. tax obligations, a more favorable result than deducting the taxes would provide. ${ }^{14}$

In a rough-and-tumble world, the foreign tax credit seems an anomaly. States do not routinely subsidize other sovereigns. ${ }^{15}$ Yet the foreign tax credit does just that, assuring ventures, like the newly expanded business described above, that if the host state collects \$1 of income tax, the United States will reduce the U.S. tax owed by $\$ 1$. Even more remarkably, the U.S. foreign tax credit forgoes any requirement of reciprocity. ${ }^{16}$

An elaborate edifice was built atop such domestic laws in the form of bilateral tax treaties. Those treaties formalized the generosity implicit in the foreign tax credit into a gentlemen's agreement governing the taxation of cross-border transactions that traces its roots back to the League of Nations.

\footnotetext{
${ }^{13}$ Those offsets allow an income tax to tax income, rather than gross receipts. I.R.C. § 164(a)(3) (allowing a deduction for "[s]tate and local, and foreign, income, war profits, and excess profits taxes").

${ }^{14}$ Graetz and O'Hear detail the origins on the foreign tax credit and the unique historical circumstances in which it arose. Michael J. Graetz \& Michael M. O'Hear, The "Original Intent" of U.S. International Taxation, 46 DUKE L.J. 1021, 1043-54 (1997).

${ }^{15}$ Within a single state, such subsidies are less surprising. Bonds issued by state and local governments, for example, enjoy an exemption from federal income tax, allowing those governments to borrow more cheaply than they otherwise would. See I.R.C. $§ 103$.

${ }^{16}$ Of course, the circumstances under which the tax credit came into existence were extraordinary. The credit was enacted in the need to rebuild Europe after WWI. See Graetz \& O'Hear, supra note 14, at 1043-54.
}

Pitt Tax Review | ISSN 1932-1821 (print) 1932-1996 (online) DOI 10.5195/taxreview.2021.132 | http://taxreview.law.pitt.edu 
Born out of a Progressive Era impulse to create mechanisms responsive to the "upheaval of industrialization" and "the growing anxiety that existing political institutions were incapable of overcoming [that] challenge," those double tax treaties embody optimism in the face of daunting challenges. ${ }^{17}$ Over time, those treaties succeeded not simply because of the material benefits they delivered to signatories, but because they bolstered the legitimacy of international tax rules. ${ }^{18}$

\section{LEGITIMACY AND THE INTERNATIONAL TAX REGIME}

In many respects, international law presents a puzzle. Given that it is "supported by so little coercive authority[,]" one might easily conclude that "the surprising thing about international law is that nations ever obey its strictures or carry out its mandates." ${ }^{19}$ Recent history, from Brexit to the U.S. withdrawal from the World Health Organization, offers a stark reminder that a state cannot be compelled to cooperate with another state, and that appeal to global or even national welfare may fail to bind a state to a cooperative arrangement. $^{20}$ Humbling delays in the Organisation for Economic Cooperation and Development (OECD) effort to bring consensus to the taxation of digital businesses underscores that troublesome reality. ${ }^{21}$

\footnotetext{
${ }^{17}$ Sabeel K. Rahman, Democracy Against Domination 54 (2016). Rahman identifies one of the four economists often credited with the regime's creation, Seligman, as one of the "Progressive Era reformists" who "sought to overcome the challenges of industrial capitalism not only by proposing alternative economic arrangements, but more importantly by developing new mechanisms and institutions to empower citizens to better contest the exercise of economic and political power." Id. at 55, 67.

${ }^{18}$ The popularity and ubiquity of bilateral tax treaties cannot be explained by the benefits they provide to states, either developing or developed. See Kysar, supra note 6, at 1832 (showing that treaties may harm developed as well as developing states).

${ }^{19}$ Thomas M. Franck, Legitimacy in the International System, 82 AM. J. INT’L L. 705, 705 (1988).

${ }^{20}$ See Eric A. Posner, Liberal Internationalism and the Populist Backlash, 49 ARIZ. ST. L.J. 795, 795-96 (2017) (discussing instances of populist backlash to the established international order-including Brexit - that have taken place since the Cold War).

${ }^{21}$ Stephanie Soong Johnston, Time to Get Serious About OECD Global Tax Deal, Saint-Amans Says, TAX NOTES TODAY INT'L (Oct. 27, 2020) (describing conflicts among wealthy states blocking consensus on digital taxes).
}

Pitt Tax Review | ISSN 1932-1821 (print) 1932-1996 (online) DOI 10.5195/taxreview.2021.132 | http://taxreview.law.pitt.edu 
A state's willingness to abide by commitments to international tax cooperation represents a particularly great leap of faith. ${ }^{22}$ A state improves national welfare by opening its borders to trade. ${ }^{23}$ But taxation should be a zero-sum game. Scholars ask Which Countries Become Tax Havens? and Why Are There Tax Havens?, but could just as easily ask why any state should be relied on to pursue the carrot of global welfare. ${ }^{24}$

The notion of "compliance pull" offers one explanation for that willingness to engage in international tax cooperation in the absence of coercive authority. ${ }^{25}$ As Thomas Franck explains, "the inherent capacity of a rule to exert pressure on states to comply" derives from the rule's legitimacy which in turn derives from a confidence that the rule serves a common good. ${ }^{26}$ Legitimacy and compliance pull do not flow inevitably from an international legal rule's virtuous aims. Rules such as the one that "makes it improper for one state to infiltrate spies into another state in the guise of diplomats" possess such a "low ... degree of legitimacy as to exert virtually no pull towards compliance." 27

${ }^{22}$ Although the goals of the international tax regime, and of U.S. international tax policy specifically, tend to be framed in terms of worldwide welfare, it seems likely that national welfare fuels the U.S. commitment to international tax cooperation. See Graetz, supra note 1, at 1390-91 ("All of the available evidence suggests that these policies were pursued because U.S. policymakers regarded it as in our nation's best interests, not because they had accepted the enhancement of worldwide economic efficiency as the appropriate policy norm.”).

${ }^{23}$ See Graetz, supra note 1, at 1374 ("The consensus of economists insists that a policy of free trade not only improves worldwide efficiency but also improves the economic efficiency of each nation that reduces trade barriers unilaterally.").

${ }^{24}$ See Adam H. Rosenzweig, Why are There Tax Havens, 52 WM. \& MARY L. REV. 923 (2010); Dhammika Dharmapala \& James R. Hines Jr., Which Countries Become Tax Havens?, 93 J. PUB. EcoN. 1058 (2009). Assuming for a moment that cooperation would be in tax havens' interest, there are several possible explanations for a refusal to do so. The first—and most sympathetic - paints a government of a tax haven as a hapless victim of forces beyond its control, no better positioned to operate a reliable dragnet for extraterritorial tax information than it is to rid itself of critical threats to public health. A second imagines a corrupt state in which a small group of local elites profit from tax evasion or avoidance, with few benefits trickling down to the broader public. Yet another imagines a population-perhaps recognizable in the Brexit vote-skeptical of international cooperation in any form and leaders all too willing to capitalize on that wariness.

$$
\begin{aligned}
& { }^{25} \text { See Franck, supra note 19, at } 712 . \\
& { }^{26} I d \text {. } \\
& { }^{27} \text { Id. }
\end{aligned}
$$

Pitt Tax Review | ISSN 1932-1821 (print) 1932-1996 (online) DOI 10.5195/taxreview.2021.132 | http://taxreview.law.pitt.edu 
The international tax regime has long enjoyed a very different status. Particularly given that the benefits of international tax cooperation tend to be diffuse while its costs can be readily quantified, states have proven surprisingly willing to grant one another foreign tax credits and to enter into double tax treaties. ${ }^{28}$ Legitimacy and the compliance pull it generates helps to explain why international tax cooperation has proven so attractive to states despite a losing political formula of clear costs and opaque advantages.

The legitimacy historically enjoyed by international tax rules comes in two distinct forms. ${ }^{29}$ The first, input legitimacy, can be thought of as its pedigree and traced to the process through which a legal rule takes shape. A statute draws legitimacy from the legislature that approves it and, indirectly, from the election of legislators themselves. The sovereignty-preserving nature of double tax treaties - each must be individually negotiated and ratified by representatives of states - nurtures input legitimacy. With roots that reach back to the League of Nations, that pedigree bolsters the international tax regime's input legitimacy. ${ }^{30}$

In addition, international regimes feed on their own success. The impact of an institution's efforts can lend it a second form of legitimacy-output legitimacy —or do the opposite. ${ }^{31}$ For example, the World Health

${ }^{28}$ Kysar, supra note 6, at 1806 (demonstrating that surprisingly little effort has been made to measure those costs). For the sake of comparison, if the benefits delivered via treaty were provided by statute, such costs would be itemized on "tax expenditure budgets." See Steven A. Dean, The Tax Expenditure Budget Is a Zombie Accountant, 46 U.C. DAVIS L. REV. 265, 289 (2012).

29 See Fritz Scharpf, Governing in Europe: EfFective and Democratic? 2 (1999) ("distinguish[ing] among two dimensions of democratic self-determination, input-oriented authenticity (government by the people) and output-oriented effectiveness (government for the people)"); Dean, supra note 8, at 560-63 (describing the significance of input legitimacy and output legitimacy for the international tax regime).

${ }^{30}$ Franck offers the military notion of "aggressive blockade" as a rule with a "high degree of recognized legitimacy" that "must not be violated lightly" because "they are well understood, enjoy a long pedigree and are part of a consistent framework of rules - the jus in bello - governing and restraining the use of force in conflicts." See Franck, supra note 19, at 707-08. Double tax treaties, albeit in a less dramatic context, exhibit all of those characteristics.

${ }^{31}$ If an international organization acts in ways that run counter to its purposes or simply acts in the interests of some but not all, its output legitimacy will suffer. See Allen Buchanan \& Robert O. Keohane, The Legitimacy of Global Governance Institutions, in LEGITIMACY, JUSTICE AND PUBLIC INTERNATIONAL LAW 29, 45 (Lukas H. Meyer ed., 2009) ("[I]f the WTO claims to provide the benefits of trade liberalisation to all of its members, but consistently develops policies that exclude its weaker members from the benefits of liberalisation, this undermines its claim to legitimacy.").

Pitt Tax Review | ISSN 1932-1821 (print) 1932-1996 (online) DOI 10.5195/taxreview.2021.132 | http://taxreview.law.pitt.edu 
Organization's success in combating smallpox supplied it with output legitimacy while its failures on AIDS did the opposite. ${ }^{32}$ The architects of the century-old international tax regime cannot boast of having eradicated smallpox, but a claim to have eradicated double taxation has gone largely unchallenged. ${ }^{33}$ Over time, influential states did well for themselves economically by embracing a neoliberal vision, providing the international tax rules with an abundance of output legitimacy. ${ }^{34}$

\section{THE END OF INTERNATIONAL TAX COOPERATION’S FIRST GOLDEN AGE}

Change has come swiftly to international tax cooperation. ${ }^{35} \mathrm{~A}$ vision of legitimacy through state-to-state cooperation designed to shield the market from procedural and substantive tax burdens collided with the hard truths of austerity, bringing a swift end to the first golden age of international tax cooperation. ${ }^{36}$ A neoliberal formula yielded to an understandable scramble for revenues after the 2008 Financial Crisis. ${ }^{37}$ Biden's 2021 "Made in America Tax Plan" unabashedly aims to "fundamentally reorient corporate taxation" to boost U.S. revenues. ${ }^{38}$

That shift can be seen most clearly in the 2010 U.S. Foreign Account Tax Compliance Act (FATCA) and its skepticism of the genteel mechanisms

\footnotetext{
${ }^{32}$ See Robert O. Keohane \& Joseph S. Nye, Jr., The Club Model of Multilateral Cooperation and Problems of Democratic Legitimacy, in EFFICIENCY, EQUITY, AND LEgITIMACY: THE MulTILATERAL Trading System at the Millennium 264, 286 (Roger B. Porter et al. eds., 2001) (using these illustrations to explain the operation of output legitimacy).

${ }^{33}$ Tsilly Dagan's demonstration that those treaties primarily serve to redistribute resources from south to north without significantly affecting the overall tax burden on cross-border activities offers a noteworthy exception. See, e.g., Dagan, supra note 2, at 980, 987.

${ }^{34}$ Double tax treaties generally receive the credit for eliminating double taxation, but may not deserve it. $I d$. at 940-41 (concluding that "treaties often just replicate the mechanism that countries unilaterally use to alleviate double taxation" while resulting in "regressive redistribution - to the benefit of the developed countries at the expense of the developing ones").

${ }^{35}$ See generally Leaman \& Waris, supra note 5.

${ }^{36}$ See Lukas Hakelberg \& Thomas Rixen, Is Neoliberalism Still Spreading? The Impact of International Cooperation on Capital Taxation, REV. INT'L POL. ECON., at 4 (2020) (noting growing discontent with respect to the dominance of neoliberalism in international taxation and its "overall aim" of "a tax system interfering as little as possible with the "natural' working of the market").

${ }^{37}$ Ruth Mason, The Transformation of International Tax, 114 AM. J. INT'L L. 353, 364 (2020).

${ }^{38}$ U.S. Treasury DeP’T, The Made in America TAX Plan (Apr. 2021).
}

Pitt Tax Review | ISSN 1932-1821 (print) 1932-1996 (online) DOI 10.5195/taxreview.2021.132 | http://taxreview.law.pitt.edu 
of international tax cooperation..$^{39}$ FATCA rejected the neoliberal vision and methods that fueled the first golden age of international tax cooperation. The I.R.S. once eliminated millions of children from U.S. tax returns by requiring taxpayers to supply Social Security numbers for dependents. ${ }^{40}$ FATCA's similarly audacious approach to addressing reporting failures spurred the creation of far-reaching global information reporting mechanisms.

Through FATCA, the United States forced private overseas firms to provide information to U.S. tax authorities and thereby eliminated the need for formal state-to-state cooperation. Unsurprisingly, the unorthodox style of FATCA also "raised a number of issues" that a collective approach would not, such as the inability of overseas actors "to comply with the reporting, withholding and account closure requirements because of legal restrictions." ${ }^{41}$ The response by other states to FATCA has taken the form of Intergovernmental Agreements (IGAs) ${ }^{42}$ and an embrace of the OECD's Common Reporting Standard (CRS). ${ }^{43}$

The CRS and IGAs reclaim the collective over the unilateral by constructing a shared legal framework to support the bulk acquisition of extraterritorial tax information. But neither generates the legitimacy and compliance pull that fueled the first golden age of international tax cooperation. An IGA allows states to intervene on behalf of the private actors that FATCA targets and gestures towards reciprocity, but still hews closely (2010)

${ }^{39}$ Hiring Incentives to Restore Employment Act, Pub. L. No. 111-147, § 501, 124 Stat. 71, 97

${ }^{40}$ Lawrence Zelenak, The Great American Tax Novel, 110 Mich. L. REV. 969, 981 (2012) ("Requiring SSNs for dependents was actually the inspiration of John Szilagyi, an employee in the research branch of the IRS. The idea was implemented in 1987 (following legislative authorization for the requirement in 1986), and approximately seven million children did indeed vanish from the nation's tax returns following implementation.").

${ }^{41}$ Press Release, U.S. Treasury Dep't, Joint Statement from the United States, France, Germany, Italy, Spain and the United Kingdom Regarding an Intergovernmental Approach to Improving International Tax Compliance and Implementing FATCA (Feb. 7, 2012).

${ }^{42}$ U.S. TREasury Dep'T, Foreign ACCOUnt TAX Compliance ACt (FATCA), https://www .treasury.gov/resource-center/tax-policy/treaties/Pages/FATCA.aspx (last visited Feb. 25, 2021) (listing IGAs with 113 jurisdictions).

${ }^{43}$ Itai Grinberg, The New International Tax Diplomacy, 104 GEO. L.J. 1137, 1150 n.46 (2016) (The OECD's Common Reporting Standard "builds on U.S. automatic information exchange efforts developed under the auspices of legislation known as the Foreign Account Tax Compliance Act (FATCA).").

Pitt Tax Review | ISSN 1932-1821 (print) 1932-1996 (online) DOI 10.5195/taxreview.2021.132 | http://taxreview.law.pitt.edu 
to FATCA's asymmetric structure. As a result, an IGA imposes different burdens on the United States and on its counterparts. ${ }^{44}$ The CRS also falls short of the reciprocity long expected of international tax cooperation. The most obvious problem lies in the refusal of the United States to participate in the CRS. This undermines the notion of shared responsibility that fueled international tax cooperation. ${ }^{45}$

A less obvious - yet ultimately more important-failure reflects the agenda-setting power of influential states. The CRS, like FATCA, supports enforcement of the personal income tax. Most poor states rely disproportionately on the corporate income tax. ${ }^{46}$ As a result, they derive far less benefit from the CRS than wealthier states such as those that make up the OECD. By failing to account for profound differences across jurisdictions, the benefits of these recent departures from traditional modalities of cooperation flow disproportionately to wealthy states.

\section{INTERNATIONAL TAX COOPERATION’S NEXT GOLDEN AGE}

For international tax rules to enjoy the compliance pull that lent them strength for close to a century, legitimacy remains essential. Fortunately, through their failures, CRS and FATCA reveal a path towards a second golden age of international tax cooperation. Their legitimacy does not rely on the dated neoliberal notions that launched the first. ${ }^{47}$ Recognizing that

${ }^{44}$ See Allison Christians, What You Give and What You Get: Reciprocity Under a Model 1 Intergovernmental Agreement on FATCA, 31 CAYMAN FIN. REV. 24 (2013).

${ }^{45}$ Given the evolution of FATCA generally, and the emergence of IGAs specifically, it is noteworthy that Treasury lacks the ability or authority to participate in the CRS. See Stephanie Soong Johnston, Koskinen Renews Call for Passage of Common Reporting Legislation, 151 TAX NOTES 1463 (2016) (describing I.R.S. Commissioner Koskinen's call for legislation providing U.S. tax authorities with the authority to provide information to other states via CRS).

${ }^{46}$ See Richard M. Bird \& Eric M. Zolt, Redistribution via Taxation: The Limited Role of the Personal Income Tax in Developing Countries, 52 UCLA L. REv. 1627, 1629 (2005) (observing that in developing countries personal income taxes "often amount to little more than withholding taxes on labor income in the formal sector" and that as a result it "plays such a small role in the tax systems of developing countries (measured either by personal income tax revenues as a percentage of total tax revenues or by personal income tax revenues as a percentage of GDP)").

${ }^{47}$ See DAGAN, supra note 11.

Pitt Tax Review | ISSN 1932-1821 (print) 1932-1996 (online)

DOI 10.5195/taxreview.2021.132 | http://taxreview.law.pitt.edu 
CRS and FATCA reflect the priorities of the top of the global economic pyramid invites an inversion to elevate the interests of the bottom. ${ }^{48}$

Creating structural mechanisms that favor the least powerful states could help to reclaim international tax cooperation's lost legitimacy. To understand what that might mean in concrete terms, consider the minimum taxes that have become popular in the wake of the 2017 tax law changes in the United States that created the Global Intangible Low-Taxed Income (GILTI) regime. ${ }^{49}$ GILTI extends FATCA's solipsistic logic by treating any jurisdiction's claim to tax income as conditioned on its exercise. If a jurisdiction does not use it - even if it imposes other forms of taxation - that jurisdiction loses that right to the benefit of the United States. ${ }^{50}$

GILTI, as quintessentially American as Johnson v. M'Intosh's doctrine of discovery, turns the right to tax into a "right of first refusal." 51 GILTI and other minimum taxes operate by "compressing the possible tax difference between high and low tax foreign countries." 52 In that, they represent the converse of tax sparing, which preserves a developing country's ability to set appropriate tax rates.

48 Alexander Ezenagu et al., What Should a 'New Deal' on International Tax Look Like for Developing Countries?, INT'L CTR. FOR TAX \& DEV. (May 28, 2020), https://www.ictd.ac/blog/whatshould-new-deal-international-tax-look-like-developing-countries/.

${ }^{49}$ See Budget Fiscal Year, 2018, Pub. L. 115-97, § 14201, 131 Stat. 2054, 2208-12.

${ }^{50}$ The ultimate incidence of GILTI and its complex mechanisms is far from clear. Kimberly A. Clausing, Profit Shifting Before and After the Tax Cuts and Job Act, 73 NAT'L TAX J. 1233, 1243 (2020) (explaining that because of technical features such as cross-crediting in some cases "GILTI tax acts as a support for the tax revenues of our trading partners").

${ }^{51}$ Susan C. Morse, GILTI: The Co-Operative Potential of a Unilateral Minimum Tax, 2019 BRIT. TAX REV. 512, 519 (2019). It would be wrong to compare GILTI to genocide, but GILTI's "right of first refusal" approach allows the United States to lay claim to revenues that traditional notions of tax policy would assign to other states when those other states fail to demonstrate a sufficient level of civilization by employing a U.S.-style income tax. Eric Kades, Dark Side of Efficiency: Johnson v. M'Intosh and the Expropriation of American Indian Lands, 148 U. PA. L. REV. 1065, 1073 (2000) (concluding that the "legal rule of M'Intosh is but one piece in the large puzzle of efficient expropriation of Indian land").

${ }^{52}$ Kimberly A. Clausing, Fixing Five Flaws of the Tax Cuts and Jobs Act, 11 COLUM. J. TAX L. $31,57(2020)$.

Pitt Tax Review | ISSN 1932-1821 (print) 1932-1996 (online)

DOI 10.5195/taxreview.2021.132 | http://taxreview.law.pitt.edu 
Tax sparing - a practice that can benefit developing states - has long been controversial. ${ }^{53}$ In practice, tax sparing occurs when a wealthy jurisdiction treats a tax that a poor state does not collect as having been paid. ${ }^{54}$ The result of that willful suspension of disbelief turns the possibility of two taxes on cross-border income into no tax at all. In theory, the arrangement allows the developing beneficiary of tax sparing to provide incentives for foreign investment. ${ }^{55}$

GILTI and other minimum taxes do the opposite, establishing an arbitrary tax "price floor." 56 Should a poor state's tax fall short of the prevailing baseline in terms of base or rate, a wealthy jurisdiction may expand its taxing jurisdiction to fill the resulting gap. ${ }^{57}$ In 2000, the OECD infamously targeted Liberia with economic sanctions after "blacklisting" the war-ravaged nation as a tax haven. ${ }^{58}$ Minimum taxes replicate that result for jurisdictions now often termed "low tax" by allowing prosperous states to collect revenue that should, according to traditional notions of international tax policy, belong to others.

Where tax sparing would affirmatively shrink a wealthy jurisdiction's right to tax, minimum taxes expand it. Both represent departures from the

${ }^{53}$ See Kim Brooks, Tax Sparing: A Needed Incentive for Foreign Investment in Low-Income Countries or an Unnecessary Revenue Sacrifice?, 34 QUEEN's L.J. 505, 513-14 (2009) (“Commentators remain sharply divided on their merits. Some emphasize their importance to low-income countries, arguing passionately in their favour. Others adamantly oppose them, citing their futility, their potential for abuse and other perverse effects.").

${ }^{54} \mathrm{Id}$. at 511.

${ }^{55}$ See Céline Azémara \& Dhammika Dharmapala, Tax Sparing Agreements, Territorial Tax Reforms, and Foreign Direct Investment, 169 J. PUB. ECON. 89, 108 (2019) ("We find that tax sparing agreements are associated with an increase of up to $97 \%$ in the stock of FDI. . . Our results suggest that the growth of tax sparing provisions in bilateral tax treaties can be an important tool to encourage FDI in developing countries.").

${ }^{56}$ G. Charles Beller, GILTI: "Made in America" for European Tax-Unilateral Measures \& Cooperative Surplus in the International Tax Competition Game, 38 VA. TAX REV. 271, 308 (2019) ("GILTI gives non-U.S. sovereigns some pricing power on tax rate and base terms . . because GILTI imposes a quasi price-floor for global MNE rate and base terms.").

${ }^{57}$ Although the tax would appear to be destined for the United States, the complex mechanics of GILTI make it difficult to determine which country will collect the losing state's tax. See Clausing, supra note 52 , at $57-58$.

${ }^{58}$ See Steven A. Dean, FATCA, the U.S. Congressional Black Caucus, and the OECD Blacklist, 99 TAX NOTES INT’L 83, 89 (2020).

Pitt Tax Review | ISSN 1932-1821 (print) 1932-1996 (online)

DOI 10.5195/taxreview.2021.132 | http://taxreview.law.pitt.edu 
Lockean notions that generally guide international tax cooperation, but with very different beneficiaries. ${ }^{59}$ Although the wealthier state can have no claim to the poor state's revenues under the benefit principle implicit in most international tax rules, the minimum tax nevertheless seizes it. ${ }^{60}$

The United States could easily adopt an approach that would distinguish between states that willfully embrace low tax policies and those that lack the resources to do otherwise. Simply put, a wealthy state collecting a minimum tax on behalf of, say, Liberia, need not keep it. That unearned tax could be transferred to the state that failed to collect it or, if appropriate, held in trust for the benefit of its residents. ${ }^{61}$ Such an approach would represent a shift away from a tendency to punish states that fail to meet our exacting standards on the design of tax laws. ${ }^{62}$

Complementing GILTI's stick with a carrot targeted at states too small or poor to manage a tax system that mirrors our own would strengthen the base of the global economic pyramid. That tax sparing 2.0 would also serve the same anti-abuse ends as a minimum tax like GILTI. Curbing tax avoidance while avoiding redistribution of tax revenues from poor states to rich ones suggests a promising path towards a new golden age of international tax cooperation.

${ }^{59}$ Implicit in nearly all international tax rules is the assumption that "each state should be entitled to revenues derived from economic activity that occurs within its borders." Steven A. Dean, More Cooperation, Less Uniformity: Tax Deharmonization and the Future of the International Tax Regime, 84 TUL. L. REV. 125, 162 (2009). This benefits principle approach echoes the "everyday libertarianism" criticized by Murphy and Nagel. See Leaman \& Waris, supra note 5, at 3 ("Similar reservations can be directed at the benefit principle or the equal sacrifice principle which, while distinct from a crude libertarianism, operate according to a fundamental yardstick of proportionality without reference to the distributional outcome of the subsequent use of fiscal resources in state expenditure.").

${ }^{60}$ The revenues claimed by minimum taxes are not being taxed pursuant to either residence or source since active income is being taxed by a country other than the source country. See Avi-Yonah, supra note 6, at 306 ("The benefits principle states that active (business) income should be taxed primarily by the country of source, and passive (investment) income should be taxed primarily by the country of residence. This is the famous compromise reached by the four economists at the foundation of the regime in 1923 and is not particularly controversial.").

${ }^{61}$ Holding the revenues in trust might be appropriate for a jurisdiction like Liberia when the OECD published its infamous blacklist of tax havens omitting Switzerland and including Liberia, a state that, at the time the OECD threatened it with economic sanctions for being a tax haven, was ravaged by years of civil war and led by a President soon to be convicted of war crimes. See Dean, supra note 58.

${ }^{62}$ See Steven A. Dean \& Attiya Waris, Ten Truths About Tax Havens: Inclusion and the 'Liberia' Problem, 70 EMORY L.J. (forthcoming 2021).

Pitt Tax Review | ISSN 1932-1821 (print) 1932-1996 (online)

DOI 10.5195/taxreview.2021.132 | http://taxreview.law.pitt.edu 


\section{4 | Pittsburgh Tax Review | Vol. 182021}

\section{CONCLUSION}

In an increasingly fractious world, the neoliberalism of the first golden age-with its utopian pursuit of economic efficiency and worldwide welfare-will not return. But cooperation could still serve a larger purpose, as it must if it is to draw strength from compliance pull. Creating structures designed to preserve a robust tax base for those states with the least while safeguarding the prerogatives of wealthy states could nurture the legitimacy essential to another golden age of international tax cooperation. Upending the America First logic of GILTI to strengthen the base of the global economic pyramid could accomplish that. Implementing that tax sparing 2.0 would deliver a win-win result for residents of rich and poor states alike.

Pitt Tax Review | ISSN 1932-1821 (print) 1932-1996 (online) DOI 10.5195/taxreview.2021.132 | http://taxreview.law.pitt.edu 